\title{
Ks. Sławomir WASILEWSKI, Pacis magisterium apud sanctum Cyprianum. Dissertatio ad doctoratum in Litteris Christianis et Classicis, Romae 2005, Pontificia Studiorum Universitas Salesiana, ss. 210.
}

Ważne zarówno dla polityki, jak i kultury oraz religii pojęcie pokoju, było już wielokrotnie pod różnymi aspektami naukowo rozpatrywane; zajmowano się również nierzadko jego semantycznym znaczeniem w starożytności (por. m.in. H.J. Sieben, Voces. Eine Bibliographie zu Wörtern und Begriffen aus der Patristik, Berlin - New York 1980, s. 73: e,,r»nh; s. 360: „pax”). Zajął się nim również w 2005 r. w swej rozprawie doktorskiej na Wydziale Literatury Klasycznej i Chrześcijańskiej Papieskiego Uniwersytetu Salezjańskiego w Rzymie ks. Sławomir Wasilewski, który postanowił zbadać jego znaczenie we wszystkich pismach żyjącego w 1. poł. III wieku biskupa Kartaginy św. Cypriana († 258), stawiając w swej tezie problem: Pacis magisterium apud Sanctum Cyprianum. W swej rozprawie pragnie, jak zaznacza we wstępie (s. 10), ukazać tym razem nie tyle zewnętrzną i polityczną stronę pokoju, przedstawianą już w wielu dotychczasowych publikacjach, rozumianego najczęściej jako brak wojny i gwałtu, ale często $\mathrm{z}$ wielu względów pomijaną jego pozytywną duchową i wewnętrzną naturę społeczną i teologiczną, mającą swe uzasadnienie nie tylko w rozumie, ale i w chrześcijańskiej wierze i dyscyplinie oraz mądrości Bożej, co ujmuje ogólnym wyrażeniem „magisterium pacis”. Chce to odczytać w myśli autora wczesnochrześcijańskiego, w którego pismach termin „pax” występuje aż 236 razy (najczęściej w listach - 147 razy), dotąd w tym aspekcie jeszcze nie przebadanego, a którego życie przez niektórych współczesnych badaczy (np. E. Peretto) nazywane jest „vita pro pace”. Ten starożytny Biskup, uczący tak często o pokoju w trudnych czasach prześladowań cesarzy Decjusza i Waleriana, może i nas, zdaniem Autora, wiele nauczyć.

Tak postawiony problem ks. S. Wasilewski stara się rozwiązać w rozprawie zbudowanej z 4 rozdziałów, poprzedzonych wykazem skrótów i wstępem, a zakończonych podsumowaniem, bibliografią i 3 indeksami (biblijnym, źródeł i imion). Wykaz skrótów (ss. 7-8) zawiera sigla cytowanych źródeł, ksiąg biblijnych i innych abrewiacji. Wprowadzenie („Introductio”, ss. 9-14) wyraża aktualność i uzasadnienie podjęcia takiego tematu, cel rozprawy, wskazanie źródeł i metodę ich rozpatrywania (aspekty: historyczny, filologiczny, literacki i teologiczny), streszczenie 4 jej rozdziałów oraz podziękowania promotorom.

Rozdział I. „Quaestiones introductoriae” (ss. 15-35), mający charakter wprowadzający, omawia 4 objaśniające tematy: najpierw znaczenie użytego w tytule terminu „magisterium” przyjmując za starożytnymi 3 jego sensy (magisterium jako: munus honestum, ius ducendi, ius docendi), potem przypomina biogram św. Cypriana, a następnie krótką charakterystykę wszystkich poszczególnych jego pism dzieląc je na pochodzące sprzed i za episkopatu, a wreszcie idąc za Thesaurus Sancti Cypriani (Turnhout 1997) przedstawia 
częstotliwość występowania terminu „pax” w poszczególnych jego pismach z podaniem szczegółowej lokalizacji i racji jego użycia. Duża częstotliwość wykorzystania tego rzeczownika, większa od innych kluczowych terminów (np. oratio, iustitia, unitas) świadczy, że Cyprian przypisywał mu ważną rolę, którą, zdaniem Autora, warto prześledzić.

Rozdział II. „Pax data” (ss. 37-97), najobszerniejszy, ma już charakter twórczy, starający się ukazać teologiczne znaczenie pokoju w oparciu o te wypowiedzi Cypriana, które go prezentują jako dar Boży. Rozdział ten można by podzielić na dwie zasadnicze części: w pierwszej (ss. 37-67) Autor przytacza najpierw i analizuje w aspekcie retorycznym fragment Ad Donatum 5 wskazując na 3 filologiczne Cyprianowe oznaczenia pokoju (,pax infestis”, „quies violentis”, „lenitas ferocientibus”), następnie omawia relację „Pax et bellum” najpierw u autorów pogańskich a potem u Cypriana, na przykładzie dwóch jego analizowanych retorycznie i teologicznie fragmentów z De catholicae Ecclesiae unitate 9 i De lapsis 16, a wreszcie charakteryzuje dwa inne Cyprianowe synonimy pokoju: „quies” i „lenitas”. W drugiej zaś części (ss. 67-97) tego rozdziału jest już konkretnie mowa o pokoju jako darze udzielanym przez trzy Osoby Boskie i przez Ducha Świętego („Spiritus Sanctus”, „Spiritus Sanctus pacis”), najobszerniej przez Chrystusa (ss. 73-93) omawiając pokój chrystologiczny w księgach Starego i Nowego Testamentu na przykładzie dwóch analizowanych retorycznie i teologicznie fragmentów z De catholicae Ecclesiae unitate 24 („Christus dator pacis”, „Dominicum magisterium pacis”, „Pax res salutaris”) i z De dominica oratione 8 („Christus dator pacis”, „Christus Deus pacis”), i wreszcie już lakonicznie - przez Boga Ojca („Deus Pater”, „Deus Pater pacis”).

Rozdział III. „Pax reddita” (ss. 99-143), równie obszerny, traktuje o pokoju przywróconym po jego w różnych okolicznościach utraceniu. W pierwszej swej części zawiera najpierw uwagi retoryczne, teologiczne i eklezjologiczne, wysnute $\mathrm{z}$ analizy fragmentu De lapsis $1 \mathrm{w}$ relacji do dobra Bożego pokoju, utraconego wskutek ludzkiej niewierności, ale odzyskanego dzięki łaskawości Bożej. Mówiąc tu o „pax reddita” Autor dysertacji nawiązuje do trudnej sytuacji Kościoła w czasie prześladowań Decjusza i Waleriana oraz stara się opisać eklezjologiczny charakter pokoju i drogę pokuty, jaką Matka Kościół wskazuje do jego odzyskania. Omawia przy tym krótko najpierw przyczyny i przebieg tych prześladowań, a następnie sytuację „upadłych” (lapsi) opisując sposób przywracania im pokoju (jedności) z Kościołem językiem św. Cypriana: „Pax reddita non temere” (non „inprudenter”, non „,fortuito”, non „,faciliter”, non ,festinanter") i „Pax reddita iuxta ordinem quendam” (,post exomologesim”, , coram ministro Dei”, ,intra Ecclesiam”), co im później gwarantowało „communicatio fraternitatis" i ,communicatio cum Deo”. W drugiej zaś części (ss. 133-143) na przykładzie 3 przeanalizowanych retorycznie i teologicznie fragmentów pism Cypriana (De catholicae Ecclesiae unitate 1 i 10, De zelo et livore 2) wskazuje na zauważone przez niego niebezpieczeństwa grożące po- 
kojowi udzielonemu i odzyskanemu - herezje i szatana („Pax et haeresis”, „Satanas hostis pacis”).

Wreszcie w najkrótszym ostatnim rozdziale IV - „Pax quaesita” (ss. 145158) Autor przypomina rady św. Cypriana, w jaki sposób pokój podarowany ludziom przez Boga podczas chrztu lub przywrócony im w Kościele przez pokutę, uczynić pokojem prawdziwie chrześcijańskim. W oparciu o wybrane teksty, które analizuje w aspekcie retorycznym i teologicznym, Autor wskazuje na pewne cnoty, bez których nie ma prawdziwego pokoju chrześcijańskiego: na cnotę miłości (De bono patientiae 15), na cnotę cierpliwości (De bono patientiae 20 ) i na cnotę sprawiedliwości (De dominica oratione 24) z przypomnieniem ich doskonałych wzorców - sprawiedliwego Chrystusa i sprawiedliwego Symeona.

W zakończeniu („Conclusio”, ss. 159-164) całej rozprawy Autor podsumowuje wysnute wnioski z wieloaspektowej analizy wychowawczej wartości pokoju (magisterium pacis) w myśli św. Cypriana zaznaczając, że świadczą o niej nie tylko przebadane zapisane jego teksty, ale cała jego duszpasterska działalność, wyrażająca się m.in. w zwoływanych przezeń synodach i dobroczynnej działalności; nie pisałby on zapewne, zdaniem Autora, tak pięknie o pokoju, gdyby nie był chrześcijaninem i biskupem Kościoła, a pozostał tylko pogańskim retorem. Z przeprowadzonych analiz Cyprianowych tekstów wynika, że prawdziwy pokój pochodzi od Boga, ma charakter teologiczny, jest wielkim darem Bożym, udzielanym w określonych okolicznościach ludziom przez poszczególne Osoby Boskie, zwłaszcza przez Chrystusa, który sam otwarcie nazywa siebie „Dawcą pokoju” (J 14, 27). W Cyprianowym nauczaniu o pokoju właśnie Bóg jest nie tylko Dawcą, ale i najwyższym Nauczycielem pokoju, co potwierdza licznie przytaczanymi cytatami biblijnymi; aby ten pokój zachować, należy, zdaniem Biskupa Kartaginy, pielęgnować cnoty miłości, sprawiedliwości i cierpliwości.

Stosunkowo obszerna „Bibliografia” (ss. 165-188) podzielona jest tradycyjnie na „Fontes” i „Studia”. W pierwszych wydzielone są 4 grupy: pisma Cypriana („Fontes Cypriani Carthaginiensis”) według najnowszego ich wydania w Corpus Christianorum (CCL 3-3C), cytowane pisma autorów chrześcijańskich („Fontes scriptorum christianorum”: 6 autorów), wykaz cytowanych autorów pogańskich („Fontes nonnullorum antiquitatis auctorum”: 25 autorów) oraz inne źródła („Fontes alii”: Biblia i Katechizm). Drugą część bibliografii stanowią słowniki i opracowania („Lexica et studia”: 320 publikacji, w tym 5 polskojęzycznych), których znakomita większość dotyczy różnorodnej tematyki Cypriana. Rozprawę kończą 3 indeksy (ss. 189-205): biblijny („Index locorum de Sacris Scripturis”), cytowanych źródeł („Index fontium”) i nowożytnych autorów („Index doctorum virorum mulierumque”) oraz spis treści („Index rerum”, ss. 207-210).

Oceniając teraz wyżej scharakteryzowaną rozprawę, trzeba najpierw podkreślić, że jest ona napisana wprawdzie nie klasyczną, ale dobrą (bez zauważo- 
nych błędów gramatycznych i literowych) łaciną, co we współczesnych czasach podnosi bez wątpienia jej wartość. Również metodologiczny zapis przypisów i bibliografii jest poprawny i nie budzi zastrzeżeń. Pod względem zaś merytorycznym stanowi ona ciekawy i ważny przyczynek do czekającej na pełne opracowanie teologii pokoju u Ojców Kościoła, z których pod tym względem najlepiej dotąd jest opracowany św. Augustyn. Ważniejsze i większe wypowiedzi św. Cypriana są poprawnie analizowane dwuaspektowo - teologicznie i retorycznie, wedle dobrze znanych Autorowi prawideł retoryki starożytnej, z dołączeniem (w notach) bogatej egzemplifikacji klasycznej, co świadczy, że jest on nie tylko dobrym teologiem, ale i dojrzałym filologiem klasycznym, dobrze znającym swoje rzemiosło.

Oprócz jednak tych walorów recenzowana rozprawa ma również, jak każde dzieło ludzkie, pewne braki i usterki, na które każdy recenzent jest szczególnie uwrażliwiony proponując ich uzupełnienie lub usunięcie.

Najpierw we wprowadzeniu brak jest całkowicie status quaestionis omawianego problemu. Autor zaznacza (s. 11), że zna opracowania na temat pojęcia pokoju u Tertuliana, Orygenesa, Euzebiusza z Cezarei, Augustyna i innych chrześcijańskich pisarzy (,novimus investigationes super notione pacis apud Tertullianum, Origenem, Eusebium Caesariensem, Augustinum vel alios christianos"), w wielu książkach są większe lub mniejsze wzmianki o pokoju nawet u Cypriana, ale brak jakiejkolwiek monografii o pokoju w pismach św. Cypriana (,non invenimus ullum opus monographicum de pace in scriptis sancti Cypriani"). Autor jednak nie popiera tych stwierdzeń, nawet w bibliografii, żadnymi publikacjami z wyjątkiem jednej dotyczącej Tertuliana (M. Papes) i jednej dotyczącej św. Augustyna (H. Fuchs), a jest ich wiele, które przytaczamy niżej. Te opracowania o pokoju u autorów wczesnochrześcijańskich należało dla dobra sprawy zebrać, przytoczyć i ocenić oraz ukazać, czy ich (zwłaszcza wcześniejszych Afrykańczyków) poglądy mogły wpłynąć na myśl Cypriana, lub ta ostatnia na poglądy późniejszych (zwłaszcza św. Augustyna). Odnośnie zaś Cypriana nie ma faktycznie monografii na temat pokoju w jego myśli, ale należało tu chyba zebrać i ocenić przynajmniej kilka większych wzmianek na temat pokoju u niego z ogólniejszych opracowań (choćby np. uwagi E. Dinklera, Friede, w RACh VIII 471-472) wykazując ich braki i potrzebę obszerniejszego opracowania.

Można również dyskutować, czy ten sam problem opracowywany przez Autora wcześniej fragmentarycznie, może być później tematem rozprawy doktorskiej, jedynie poszerzonym o zakres źródeł - rozciągnięty na wszystkie dzieła. Autor bowiem uzasadniając racje podjęcia tematyki pokoju u św. Cypriana, m.in. zaznacza (s. 11), że podjęta dysertacja o pokoju będzie kontynuacją wcześniejszych jego prac na ten temat: przy bakalaureacie (pt. Cypriani Carthaginiensis mens de pace in opere quod inscribitur „De dominica oratio$n e ”)$ i większej przy licencjacie (pt. Cypriani Carthaginiensis mens de pace in 
operibus quae „De catholica Ecclesiae unitate” et „De dominica oratione” inscribuntur"), podjęta zaś rozprawa doktorska dotyczyć będzie wszystkich dzieł Cypriana.

Jeśli chodzi o strukturę całej rozprawy, to wydaje mi się, że mało twórcza i zbyteczna jest środkowa część jej I rozdziału „Quaestiones introductoriae” (p. 2. „Imago vitae Cypriani”; p. 3. „Opera Cypriani”, ss. 18-30), która jest praktycznie powtórzeniem znanych podręcznikowych wiadomości. Przy objaśnianiu zaś pojęcia „magisterium” (p. 1), które Autor omawia ogólnie i trójaspektowo (magisterium: „ut munus honestum”, ,ut ius ducendi”, , ut ius docendi”), wypadałoby również uwzględnić (bo praca ma z założenia ukazać teologiczną stronę pokoju) również eklezjalny lub chrześcijański aspekt tego pojęcia, uwzględniając przy tym choćby uwagi Y. Congara (Histoire du mot „magisterium”, „Concilium F"117:1976, 129-141; Pour une histoire sémantique du terme „magisterium”, „Revue des Sciences Philosophiques et Théologiques” 60:1976, 85-98), którego brak w bibliografii.

W całej zaś rozprawie, która z założenia ma ukazać teologiczną stronę pokoju, zbyt mało jest odniesień do autorów wczesnochrześcijańskich (Tertulian 5x, Hieronim 2x, Augustyn 1x, Izydor 1x, Laktancjusz 1x, Poncjusz 1x = 11x), a jeśli są, to nie ma o nich mowy w tekście, ale ich drobne wypowiedzi służą jedynie jako „ozdóbki” w przypisach. Cała argumentacja tezy, oprócz wypowiedzi Cypriana, opiera się w zasadzie na Biblii (35x ST i 95x NT = $130 x$ ) i autorach klasycznych (Cyceron 54x, Tytus Liwiusz 33x, Seneka 11x, Swetoniusz 4x, Apulejusz 3x, Florus 3x, Tacyt 3x, Wobiskus Syrakusius 2x, Geliusz 2x, Pliniusz Młodszy 2x, Poncjusz 2x, Terencjusz 2x, Waleriusz Maksym 2x, Ampeliusz 1x, Fronton 1x, Platon 1x, Kwintylian 1x, Seneka Młodszy 1x, Sekstus Pompejusz Festus 1x, Warron 1x, Wellecjusz 1x = 131x), co zdaje się sugerować, iż bazuje ona na dokumentacji zebranej w publikacjach poświęconych pokojowi w okresie przedchrześcijańskim, których w załączonej bibliografii jest faktycznie najwięcej. Przy omawianiu zaś relacji autora chrześcijańskiego do pokoju, wypadałoby dla dobra sprawy powiedzieć coś (przynajmniej w oparciu o publikacje), co na ten temat sądzili jego chrześcijańscy poprzednicy i następcy, by należycie ocenić oryginalność jego myśli i jej wpływ na spadkobierców. Tymczasem brak tego zarówno w treści rozprawy, jak i w załączonej bibliografii, w której ściśle patrystycznych publikacji na temat pokoju jest bardzo niewiele (zaledwie 3), a można by ich wskazać przynajmniej jeszcze kilka, dotyczących zarówno okresu przed Cyprianem (np. J. Fantini, Notas al

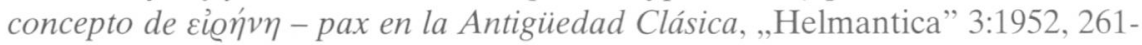
264; D. Ruiz Bueno, La paz en la Iglesia primitiva. Consideraciones sobre la Didachè y la 1. Clem., „Helmantica” 3:1952, 135-173; A. Kerrigan, The notion of peace in the writings of Clement Alex., w: XXXV Congr. Euch. Internat. Sessiones de Estudio, II, Barcelona 1954, 430-433; C. Manthey, Il concetto di „pax” nelle monete Romane da Augusto a Nerva, RivAC 29:1953, 94; M. Viano, 
Contributo alla storia semantica della famiglia latina di „pax”, „Atti dellAccademia delle Scienze di Torino" 88:1953, 168-183; C. Tibiletti, Il senso eschatologico di pax et refrigerium e un passo di Tertulliano, „Maia” 10:1958, 209-219; A. Portolano, Etica della pace nei primi secoli del cristianesimo, Napoli 1974; M. Toschi, Pace e Vangelo. La tradizione cristiana di fronte alla guerra, Brescia 1980; V. Grossi, I nodi della pace nella storia del cristianesimo, w: La pace del Regno, Torino 1983, 73-95; z polskich: W. Myszor, Chrześcijanie wobec świata. Problem wojny $i$ pokoju $w$ pierwotnym chrześcijaństwie, SSHT 15:1982, 231-241; A. Eckmann, Koncepcja pokoju i wojny w nauczaniu Ojców Kościoła, w: Patrystyczne dziedzictwo społecznej nauki Kościoła, Gniezno 1996, 57 72), jak i po nim.

Wydaje się, że przedstawiane w rozprawie magisterium pacis u Cypriana zyskałoby wiele, jeśliby Autor ukazał także jego wpływ na późniejszych autorów wczesnochrześcijańskich, jak np. na św. Grzegorza z Nazjanzu, który wygłosił trzy mowy o pokoju $(6,22,23)$, a zwłaszcza na Afrykańczyków, szczególnie na św. Augustyna, który pod tym względem jest najbardziej opracowanym Ojcem Kościoła (por. np. F. Wiesenthal, Die Wandlung des Friedensbegriffs von Augustins zu Thomas von Aquin, München 1949; Y.M. Congar, „Pax” chez Saint Augustin, w: Bibliothèque Augustinienne, t. 28, Paris 1963, 711-713; J. Laufs, Der Friedensgedanke bei Augustinus. Untersuchungen zum 19. Buch des Werkes „De civitate Dei”, Wiesbaden 1973; H.J. Diesner, Die Ambivalenz des Friedensgedankes bei Augustin, WissZsUniv. Halle - Wittenberg 1961, 877-880; T. Renna, The idea of peace in the Augustinian tradition, „Augustinian Studies” 10:1979, 105-111; z polskich: S. Bross, Idea pokoju u św. Augustyna i jej wpływ na średniowiecze, w: Święty Augustyn, praca zbiorowa pod red. S. Brossa, Poznań 1930, 7-26; S. Budzik, Doctor pacis. Theologie des Friedens bei Augustinus, Innsbruck 1988; tenże, Wizja pokoju u św. Augustyna, TST 11:1992, 119-131; J. Eska, Idea pokoju u św. Augustyna, DzJ 9:1953, nr 10, s. 8; S. Kowalczyk, Filozofia pokoju u św. Augustyna, VoxP 8:1988, z. 15, 831857; M. Chuchra, Papież Grzegorz Wielki obrońca pokoju w świetle swoich listów, RTK 42:1995, z. 4, 5-24); żadnej z wymienionych wyżej publikacji nie przytacza prezentowana w dysertacji bibliografia.

Wracając z kolei do Biblii, którą bardzo często cytował św. Cyprian, a przytaczane przez niego biblijne cytaty stanowią cenne świadectwo przedhieronimowego łacińskiego przekładu Pisma Świętego (Afra?). Na te cytaty powołuje się również Autor rozprawy przy udowadnianiu teologicznej strony pokoju. Wypadałoby więc, żeby w swej rozprawie poświęcił choćby kilka uwag na temat łacińskiego tekstu Biblii w Afryce za czasów Cypriana, a w bibliografii wskazać zainteresowanym na jakieś publikacje na ten temat (choćby np. P. Capelle, Le texte du Psautier latin en Afrique, Rome 1913, 23-30 (Cyprian); M. Stenzel, Zur Frühgeschichte der lateinischen Bibel, „Theologische Revue” 49:1953, 97-103; Vetus latina. Die Reste der lateinischen Bibel, hrsg. B. Fischer, 
Freiburg 1951-1969; H. von Soden, Das lateinische Neue Testament in Afrika zur Zeit Cyprians, TU 33, Leipzig 1909; P. Glaue, Die Vorlesung heiliger Schriften bei Cyprian, ZNW 23:1924, 201-213), tymczasem Autor zaznacza we wstępie (s. 12) i w wykazie wykorzystanych źródeł (s. 169: „Fontes alii”), że będzie się posługiwał nowym wydaniem Wulgaty z 1986 roku (,quod pertinet ad locos Veteris et Novi Testamenti, quos in hac nostra tractatione laudavimus, usi sumus editione Bibliorum Sacrorum «typica» editione quae vocatur Nova Vulgata"), a przy greckich tekstach Nowego Testamentu - wydaniem E. Nestlego - B. Alanda (The Greek New Testament, Stuttgart 1993); to mniej więcej tak, jakby przy tłumaczeniu tekstów św. Cypriana chciał się posługiwać Biblią Tysiąclecia.

Na zakończenie jeszcze kilka drobnych krytycznych uwag na temat końcowych składników omawianej rozprawy. Najpierw odnośnie bibliografii, którą zamiast prosto podzielić na źródła (pierwszorzędne i drugorzędne) i opracowania, Autor swoiście dzieli i dwuznacznie nazywa: „Fontes Cypriani Carthaginiensis” (pisma Cypriana), „Fontes scriptorum christianorum” (autorzy chrześcijańscy), „Fontes nonnullorum antiquitatis scriptorum” (autorzy niechrześcijańscy), „Fontes alii”: tego rodzaju tytuły nie tylko, że są niejasne, ale mogą sugerować, że chodzi tu o wykaz źródeł, które wykorzystywali św. Cyprian, autorzy chrześcijańscy i autorzy niechrześcijańscy. Ponadto nie wiadomo dlaczego wśród autorów niechrześcijańskich znalazł się (s. 167) autor chrześcijański: „Isidorus, Etymologiarum sive originum libri $X X$ ”, a dzieło Tytusa Liwiusza $A b$ Urbe condita rozpisane zostało na poszczególne księgi aż w 17 pozycjach. Drugą część bibliografii, zatytułowaną „Lexica et studia”, choć w zasadzie metodologicznie jest poprawnie zapisana (rzadkie literówki, jak np. s. 174: „Stuttgard”; s. 176: „Limosna”; s. 177: „,contemporany”), chyba lepiej byłoby rozdzielić na „Studia” i „Lexica”, a do drugich, ukazujących semantyczne znaczenie terminu „pokój” (P. Chantrine, H. Frisk, G.W.H. Lampe, A. Blaise, A. Forcellini) dodałbym Theologisches Wörterbuch zum Neuen Testament G. Kittela oraz (ponieważ Autor jest Polakiem (Stownik grecko-polski Z. Abramowiczówny i Stownik tacińsko-polski M. Plezi. Wreszcie dziwnie i niejasno został nazwany ostatni indeks cytowanych autorów nowożytnych: ,, Index doctorum virorum mulierumque" (s. 201). Mimo tych drobnych braków i usterek recenzowana rozprawa warta jest lektury, bo stanowi bez wątpienia, jak zaznaczono wyżej, cenny i ważny przyczynek do historii teologii, zwłaszcza teologii pokoju u Ojców Kościoła oraz przybliżenia myśli żyjącego 1750 lat temu św. Cypriana.

Ks. Stanisław Longosz - Lublin, KUL 